
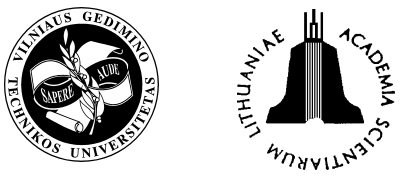

\title{
HOW HAS THE CONTINUATION OF 'SOFT' BUDGET CONSTRAINTS AFFECTED THE PERFORMANCE OF STATE-OWNED ENTERPRISES AND IS THE ALTERNATIVE OF PRIVATISATION FEASIBLE?
}

\author{
Bryane Michael \\ Linacre College, Oxford University, Oxford, OX1 3JA UK \\ E-mail: bryane.michael@linacre.ox.ac.uk
}

Received 12 May 2006; accepted 25 July 2007

\begin{abstract}
This paper will argue that the continued existence of state-owned enterprises (SOE) soft budget constraints, while adversely affecting SOE performance, reflects wider problems in the regulation of Chinese industry. As such, simple recourse to privatisation will not address the deep structural factors, such as over-politicisation and under-regulation of the private sector, which affect SOE performance. Section I of the paper will discuss the "direct" effects of soft budget constraints on SOE performance in China. Section II will address the "indirect effects" of soft budget constraints through their effects on the competitive environment vis-a-vis private sector firms. Section III will address the issue of privatisation and discuss the broader factors which affect both the extension of soft budget constraints and low SOE performance.
\end{abstract}

Keywords: soft budget, state-owned enterprises, township and village enterprises, privatisation, China.

\section{Introduction}

The economic reforms undertaken in China after 1979 helped to establish what has become known as the "dual track" system. These policies consisted of the liberalisation of the agricultural sector (through the disbanding of the agricultural collectives) and the steady decrease in the importance of state owned enterprises (SOEs). The decrease in the economic importance of SOEs has been concomitant with the increase in the number of non-state (de novo) enterprises and more importantly policies establishing the township and village enterprises (TVEs) [1]. This "nonstate sector" has grown from providing $22 \%$ of national production in 1979 to $72 \%$ in 1999 [2]. Such growth, moreover, has been achieved without resort to mass privatisation or widespread restructuring of state-owned enterprises (SOEs) as in Eastern Europe and the former Soviet Union. Instead, SOEs have been indirectly discouraged by policymakers - partly by changing the relative prices paid for administratively planned goods versus market goods. For example in 1985, planned prices constituted $64 \%$ of output value while in 1993, were only $18 \%$ of output value (Palanca, [2]). The resulting price differential encouraged producers to move to private sector activities. However, such "benign neglect" of the SOE sector has not included the large-scale reduction of under-costed state-provisioned capital (or "soft budget constraints") leading commentators such as Steinfeld to note that "the imposition of hard budget constraints should be the prime goal of transitional reform" [3, p. 247].

This paper will argue that the continued existence of SOE soft budget constraints, while adversely affecting SOE performance, reflects wider problems in the regulation of Chinese industry. As such, simple recourse to privatisation will not address the deep structural factors, such as overpoliticisation and under-regulation of the private sector, which affect SOE performance. Section I of the paper will discuss the "direct" effects of soft budget constraints on SOE performance in China. Section II will reflect the "indirect effects" of soft budget constraints through their effects on the competitive environment vis-a-vis private sector firms. Section III will address the issue of privatisation and discuss the broader factors which affect both the extension of soft budget constraints and low SOE performance.

\section{An overview of soft budget constraints and SOE performance in China}

During the post-1979 reform period, there appeared to be a correlation between decreasing SOE performance and the continuation of SOE soft budget constraints. Measuring SOE "performance" in output terms, their contribution to industrial output fell from about $77 \%$ in 1980 to about $30 \%$ in 1997 [4]. Measuring "performance" in profit terms, the profit rate of SOEs which started at about $18 \%$ in 1980 
has slipped to negative levels by 1996 (ibid). Expressed as return to investment, industrial SOEs produced 81 cents in profit for every dollar invested in 1985 (ibid). By 1997, the profit to investment ration fell to 9 cents to every dollar. ${ }^{1}$ Such a decrease in performance has been concomitant with a high level of state subsidisation of capital to SOEs (the extension of "soft budget constraints"). Such subsidisation what Stienfeld [3] calls "soft subsidisation" - often occurring through state-owned banks (SOBs), took the form of debt-for-equity swaps, the roll-over of non-performing loans, non-performing foreign debt and SOE stock market floats [2]. Palanca notes that $75 \%$ of all bank lending went to SOEs, whereas private enterprises only received $1 \%$ of bank financing. Yet, in 1978, non-performing loans represented about $97 \%$ of the Chinese banking sector portfolio while in 2000 this ratio fell to $78 \%$ and in aggregate terms, non-performing loans account for roughly over $50 \%$ of GDP.

There is a number of direct mechanisms by which soft budget constraints may affect SOE performance. ${ }^{2}$ First, while soft budget constraints would result in the short run in lower factor prices, in the long-run they result in higher SOE input prices due to increased labour and capital demand $[2,6] .{ }^{3}$ Thus the effects of soft budget constraints on SOE performance would depend on the time-frame. Second, soft budget constraints may give rise market power and consequently increased firm size. ${ }^{4}$ Thus the effects on SOE performance would depend on industrial structure. Third, within the firm, soft budget constraints may increase managerial power within firms and discretion because managers are not disciplined by markets [6]. Thus, the effects on SOE performance would depend how performance is defined; if performance is the defined as generating returns to SOE "stakeholders" such as managers or employees, then managerial discretion has increased "performance." Fourth, soft budget constraints may result in resource wedges within the SOE sector itself. Given that budgetary subsidies are allocated on political grounds rather than economic ones, capital is not allocated to the most productive activity. Thus the effects of capital subsidies on SOE performance would depend on the link between the political decision role to allocate subsidies and past performance [3]. Fifth, soft budget constraints may lead to changes in managerial relative risk aversion. If managers adopt a "don't fix it if it isn't broken"

1 Sun [5] using simple and unconvincing regression analysis finds a negative correlation between soft budget constraints (proxied as central government control) and productivity.

2 For the purposes of this essay, I will classify "direct" effects as effects which influence operational variables within the firm. "Indirect" effects will be strategic effects on the SOE due to changes in the competitive environment resulting from factor or goods price wedges between the SOE and non-state enterprise sectors.

3 Such wage and interest rate "pushes" are due to "external diseconomies" (though Naughton [6] does not call them as such).

4 Depending on the elasticities, lower marginal costs in a monopolistic setting leads to increasing quantity. Given that many of the Chinese state-owned industries have relatively low demand elasticities, these effects are likely to exist and be pronounced. mentality, then risk aversion rises and a consequent lack of performance-enhancing restructuring ensues [6]. If managers adopt a "sense of safety" from a smooth and guaranteed stream of subsidies, this may result in an increase in performance-enhancing restructuring (especially with the government contracts and high opportunity of future employment in the private sector [7,8]. Sixth, the continuation of soft budget constraints affects performance by encouraging the firm to engage in activities not directly related to their business. In many cases, soft budget constraints represent the result of a tacit agreement whereby SOEs are assumed to provide public services or prop up the pension system [7].

\section{The pitfalls of partial reform}

Soft budget constraints not only have "direct" effects on state-owned enterprises, but also "indirect effects" to the extent that they affect the competitive environment visa-vis the non-state sector. Some sanguine authors such as Naughton [6] suggest that SOEs will simply "shrink away" while others such as Murphy et al. [9] stress the importance of SOE reform. There is a range of intermediate opinions between these two views of SOE reform.

Naughton [6] argues that overall economic reform will result from the growth of the non-state sector - causing a phasing out of the state sector as the economy "grows out of the plan." There are two varieties of this argument. The first refers to a simple phasing out. Accordingly, with the incipient growth of the non-state private sector, "capitalist" or entrepreneurial interests are created which are invested in economic change. At the same time, such change demonstrates to policymakers the utility of encouraging private sector growth [2]. The second argument is reminiscent of the Lewis dual sector model except that the new private sector is supposed to draw labour and capital out of the old SOE sector - thereby "modernising" the economy. ${ }^{5}$ In this type of model, the SOE sector does not simply whither away but is a resource for a burgeoning private sector. In the first model, SOE performance may remain constant over time (if at a lower level than the private sector) while in the second model SOE performance must decrease over time to release resources to the private sector. Soft budget constraints then either would only artificially prop up performance or hasten the decline the SOE sector depending on the effects discussed in the last section.

However, there are problems with the "growing out of the plan" type arguments. First, it commits the post hoc, ergo promptor hoc fallacy when Naughton [6], for example, claims that "entry occurs quickly if there is opportunity." Non-entry is unobserved and the degree to which

\footnotetext{
5 Palanca [2] notes that labour movements between the old inefficient and new efficient industrial sectors are political difficult to accomplish because such moves are not always Pareto improving. He also notes that in the Chinese context, unlike in the Eastern European context, the burgeoning non-state enterprise sector also attracts labour from rural agricultural production whose strictly higher wages do promote Pareto improving labour movements.
} 
SOEs "drag down" the non-state sector can only be indirectly estimated. Second, $70 \%$ of small SOEs have been restructured or privatised. Thus the de novo sector is not simply replacing the SOE sector, but that reform activity facilitates the orderly transfer of factors of production [7]. As such, soft budget constraints in a "partial reform" economy affect the relative distribution of capital and credit.

For example, in the Murphy et al. [9] model, partial reform encourages SOE corruption and private "profiteering." Soft budget constraints would result in the extra availability of credit to acquire the capital and labour resources necessary to produce an intermediary input (such as timber). If the intermediary is a supplier to two sectors (the state and non-state enterprise sectors), then the private sector will draw more resources which are subsidised (sometimes in black markets from the SOE sector). They may then charge epsilon less than the state price and keep any profits. The existence of profit incentives draw firms into the private sector - thereby expanding the draw on subsidised inputs and resulting in decreased sales to the public sector firms. The public (or SOE) sector then may resort to bribery for resources in the presence of the shortage caused by high non-state private sector demand. If SOEs are given a delivery quota (such as through the "contract responsibility system"), then production and welfare may be highergiven the adequate enforcement of the quota. Yet, the most inefficient firms are most quota constrained, thus having higher marginal (and thus social) costs.

There are number of impacts of "partial reform" of soft budget constraint effects on SOE performance. First, as highlighted by Murphy et al [9]. Steinfeld [3] also discusses this point, credit subsidies may lead to corruption through the politicised acquisition of inputs. Second, if soft budget constraints take the form of lending from state-owned credit institutions, partial reform may lead to increased or unsustainably high debt burdens. As their profitability falls, SOEs may require more subsidies or bail-outs from the state owned banks [3]. More of these implicit bail-outs will increase the debt burden, leading either to decreased focus on profitability or increasing input costs which again reduce competitiveness [7]. ${ }^{6}$ Third, soft budgets may inhibit product or process innovation if competitive advantage is gained through corruption [6]. Fourth, unlike Murphy et al. [9] which see the private sector drawing resources away from SOEs, Gang [4] sees the opposite effect of the SOE sector drawing resources away from the productive sector through the banking sector leading to a "credit crunch." If state owned banks are responsible for the relative allocation of credit between SOEs and non-state enterprises, then performance of both the state and non-state enterprise sector falls because of the low marginal productivity of capital in the state sector and the quantity-restricted (yet highly productive) level of credit extended to non-state sector.

\footnotetext{
6 There are a number of "second-order" effects which may ensue from such subsidisation including increased "systemic risk", "creditor passivity", the creation of "expectations traps", moral hazard and adverse selection, and "negative value added". A discussion of these issues, while pertinent, would be too complicated for this essay.
}

\section{Is privatisation the only answer?}

The declining productivity of the SOE sector, along with its negative effects on non-state private sector development, suggests that SOE reform must be undertaken. One way to treat such reform would be to privatise the SOE sector [10]. Noughton [6] suggests that now, unlike in the past, privatisation would be possible due to the progress already made. Privatisation would help reduce the budget problems plaguing the public sector through generating sales revenue and reducing subsidies [7]. Privatisation would also help capitalise the equities market and provide funds for the developing private sector. Privatisation would moreover provide a way to help capitalise SOEs which does not rely on soft budget constraints - thus helping to provide hard budget constraints.

Yet, privatisation is not a certain way of eliminating soft budget constraints. If privatised firms are subsequently acquired by investment funds or banks whose portfolios consist of a large proportion of non-performing assets, then this creates the same incentives for firms (who will act on the assumption of a future government bail-out) and creates the same responsibility for the government (who must bail-out highly indebted banks rather than enterprises due to the risk of systemic economic effects and political pressure by adversely affected groups). Second, if state owned banks gain control of SOE governance through debt-forequity swaps, then soft-budget constraints will simply "pass through" the banking sector and effective ownership will remain in state hands. Third, if "insiders" (management and workers) obtain control, then there could be worse governance than firms overseen by the government [11]. "In China today, the state firms that exhibit behaviour most associated with private enterprise in the West - value maximisation, strict budgeting, rational investment strategies, efficiency maximisation - happen to be among the least privatised in the country... Proximity to some forms of state control is affecting performance, but in the opposite way from what traditional property-rights theory would predict" [3]. Steinfeld calls this the "the great paradox of Chinese SOE reform" [3, p. 38].

One solution would be to engage in restructuring (combined with hard budget constraints on lending institutions such as state owned banks) necessary to eliminate the need for soft budget constraints. By restructuring (whether it is deep, strategic or reactive), this would increase profitability. Restructuring could also pave the way for later privatisation as well as provide the private sector with high quality inputs and intermediate goods as well as demand for final goods (depending on the relevant elasticities). Naughton [6] optimistically notes that "state performance can be improved" and most of the authors seem to take this point of view.

However, both restructuring and privatisation miss the deeper structural elements affecting SOE productivity [10]. There are a number of "excluded variables" in the analysis. First, the role of market institutions (including regulation). Without stable and well-defined property rights and a transparent system of corporate governance, then privatisation, 
restructuring or any other micro-reform measure would not be undertaken (due to time inconsistency problems). ${ }^{7} \mathrm{Sec}-$ ond, soft budget constraints affect the entire system creating distortions in the allocation of capital [7]. The entire Chinese productive sector has been based on resources being allocated for political objectives - "factories were being commanded not to be profit maximisers, but rather to give primary importance to governmental social and political objectives" [7, p. 284]. Just as Janos Kornai [12] noted, the economic system may follow the political system and thus political reform must be the first step toward removing soft budget constraints. Performance of the SOEs depends not so much on SOEs in themselves, but the political impacts on costs and revenues due to social policy. Given that the target of reform is to transform China into a "socialist market economy", such reform does not look feasible in the short-term [10].

\section{Conclusion}

The continuation of "soft budget constraints" in China has adversely affected the performance of state-owned enterprises. The alternative of privatisation is not feasible at present given the stated goal of Chinese reform centres on transforming China into a "socialist market economy".

\section{References}

1. CHANG, C. and WANG, Y. The nature of the township-village enterprise. Journal of Comparative Economics, 1994, Vol 19, No 3, p. 434-452.
2. PALANCA, E. H. China's economic growth: implications to the ASEAN (an integrative report), PASCN Discussion Paper No 2001-01.

3. STEINFELD, E. Forging reform in China: the fate of stateowned industry, 1999.

4. GANG, F. Progress in ownership changes and hidden risks in China's transition. World Bank Transition Newsletter, MayJune, 2002, 13(3).

5. SUN, J. State-owned enterprises in China: soft budget constraints and competition. Paper presented at the International Society for New Institutional Economics. Sept 16-18, 1999. Washington, D.C., USA.

6. NAUGHTON, B. Growing out of the plan. Cambridge, Cambridge University Press, 1995.

7. LARDY, N. China's unfinished economic revolution. Brookings, 1998.

8. DEWATRIPONT, M.; ROLAND, G. Transition as a process of large-scale institutional change. Economics of Transition, 1996, Vol 4, No 1.

9. MURPHY, K.; SCHLEIFER, A.; VISHNY, R. The transition to a market economy: pitfalls of partial reform. Quarterly Journal of Economics, 1992, Vol 107, No 3.

10. DU, J.; ZHANG, Y. Unchaining China's SOEs: interviews with ten leading economists on SOE reform. Harvard China Review, 1988, 1(1).

11. MA, S. Understanding China's reform: looking beyond neoclassical explanations. World Politics, 2000, Vol 52, No 4, p. 586-603.

12. KORNAI, J. The soft budget constraint. Kyklos, 1986, Vol 30, p. 3-30.

\section{KAIP „MINKŠTOJO“ BIUDŽETO TRUKDŽIAI DARO IૃTAKĄ VALSTYBINIŲ İMONIŲ VEIKLOS REZULTATAMS? AR VEIKSNIOS PRIVATIZACIJOS ALTERNATYVOS?}

\section{B. Michael}

\section{Santrauka}

Straipsnyje autorius vertina vieną iš didžiausių ekonomikos transformacijas patiriančių šalių pasaulyje - Kiniją. Pagrindinė straipsnio užduotis - i̇vertinti, ar iki šiol propaguojama Kinijos valstybinių i̇monių „minkštujų“ biudžetu politika nedaro neigiamo poveikio jų veiklos rezultatams, kartu atskleidžiant platesni Kinijos pramonès reguliavimo diapazoną. Privatizacijos bumas negali išvesti Kinijos ekonomikos iš gilių struktūrinių gniaužtų, tokių kaip perdètas ūkio politizavimas, privataus sektoriaus nereguliavimas, kurie daro aiškią itaką valstybinių i̇monių veiklos rezultatams. Todèl 1-oje straipsnio dalyje bus diskutuojama apie „tiesioginius“ „minkštujų“ biudžetų padarinius Kinijos valstybinių i̇monių valdymui. 2-oje straipsnio dalyje bus dėstoma apie „tiesioginius“ „,minkštujų“ biudžetų padarinius per konkurencingumo aplinkos prizmę, supriešinant valstybines įmones su privačiomis. 3-ioje straipsnio dalyje keliamas privatizacijos klausimas, diskutuojama dèl kitų veiksnių, kurie lemia tiek „minkštujų“ biudžetų apribojimus, tiek žemus valstybinių įmonių veiklos rezultatus.

Reikšminiai žodžiai: „minkštasis“ biudžetas, valstybinès įmonès, miesto ir kaimo vietovių įmonès, privatizacija, Kinija.

Bryane MICHAEL. Lecturer, Dept of Development Studies, Linacre College, Oxford University (the United Kingdom). The author is active in writing essays and comments on current socio-economic and public issues on websites and academic discussion forums. He has a number of book chapters and journal articles in the fields of his scientific interest, such as public sector management, anticorruption, corporate governance, international development, organisational strategy, international business.

\footnotetext{
7 The specific time inconsistency in this case would be the ex ante sunk cost involved in reform while having limited enforceable property rights in ex post returns accruing to these sunk costs.
} 